\title{
A New Development Technology? South Asian Biometrics and the Promise of State Security and Economic Opportunity
}

Jennifer L. Fluri ${ }^{1 *}$, Paul S. B. Jackson ${ }^{2}$ and Dinesh Paudel ${ }^{3}$

${ }^{1}$ University of Colorado-Boulder, Geography Department

${ }^{2}$ Department of Geography, University of Delaware

${ }^{3}$ Department of Sustainable Development, Appalachian State University

\begin{abstract}
This paper examines the intra- and inter-state usage of biometrics as a "new" technology of development and neoliberal security in South Asia. We view developmental use of biometrics as a tool for integrating the vast majority of poor and marginalized people as visible and calculable economic subjects. We examine the ways in which biometrics translates people into data for the purposes of state, security, and economic legibility. In this paper, we explore biometrics at the intersection of geopolitics, biopolitics, and development to highlight the promise and pitfalls of "technological progress" as a new development strategy.
\end{abstract}

\begin{abstract}
"Authorities in India are investigating how Hanuman, the monkey god, has been issued a biometric identity card. The card photo features the character from the Hindu epic Ramayana wearing gold and pearl jewellery and a crown. It emerged when a postman attempted to deliver the card, but could not find a Hanuman at the address."

$-\mathrm{BBC}^{1}$
\end{abstract}

Whether this "ID of the Gods" was a prank or a form of sabotage is perhaps inconsequential, rather we take note that the problem in the system was only realized when the card failed to be delivered. Unique Identification Authority of India (UIDAI) also known as Aadhaar was launched in 2009 and aims to issue an ID card with a 12-digit unique number to all of India's 1.2 billion citizens with biometric details - iris scan, fingerprints and photographs. The Aadhaar/UIDAI program offers an individualized system of existing state welfare and development programs. Proponents of biometrics promise a future that is secure and profitable, enabling the free movement of goods and people, while curtailing corruption and terrorism. The dreams of massive state development projects, the national ID program being merely the latest iteration, are rarely shaken from their slumber in the plans and speculations of their proponents, while the practice and everyday lives of those people who interact with these systems require further attention by geographers. Hanuman's ID reminds us, according to Gupta (2012, 9), of "the sheer contingency underlying the workings of a supposedly highly rationalized, bureaucratic state." Gupta questions how state bureaucracies produce arbitrary outcomes under the guise of provisioning care, development and security.

This paper provides an overview of biometrics research in Human and Development Geography, and related social sciences. The increase in intra- and inter-state usage of biometrics data as an emerging development technology requires further inquiry, and this paper outlines the extant literature and calls for more research on biometrics in the global south. By focusing on South Asia, we provide differentiated examples of biometrics usage in order to examine the 
incorporation of biometrics as a "new" technology of development and neoliberal security. Various biometrics systems have been developed in the U.S. and sold to or shared with countries in South Asia. India was recently identified as South Asia's "geographic anchor" by the U.S. Department of State's Principal Deputy Assistant Secretary for South and Central Asian Affairs, because of India's broad economic growth, and shared U.S. values. India's geopolitical and economic significance in the region includes working with the U.S. to provide economic development assistance to Nepal and Afghanistan. India has undertaken the largest national biometric enrollment project in the world. The Afghanistan government's biometrics program seeks to identify and categorize citizens, identify insurgents and improve security toward economic growth. Biometric technologies have been implemented by development organizations in Nepal in an effort to decrease fraud, and this technology has been used as part of recovery efforts after the April 2015 earthquake.

The relationship between security and development has a long and intertwined history, while biometrics offers "new" technological fixes for the security "problem" (Duffield, 2007, Graham, 2005, LeBillon, 2008, Silvey and Rankin, 2008, Silvey, 2010). We view this technological "fix" as a tool for integrating the so-called bottom billion (Collier, 2007) as quantifiable subjects of economic development and state security. Our examination of biometrics intersects theoretically with biopolitics and geopolitics to highlight the promise and pitfalls of "technological progress" as a development/neoliberal security strategy. Technologies evoke neutral universal goals, yet on the ground, biometric identification differentially reconfigures social relations and development problems in particular geographic places.

By examining biometrics in South Asia, this review seeks to advance contemporary theories and empirical analysis of biopolitics. Drawing on Foucault's theoretical analyses on state discipline of citizens and non-citizen "others" through various techniques of corporeal control, our investigation into the biopolitics of biometrics will incorporate the emerging literature on biotechnologies and the bio-economy by social scientists. Biometrics has increasingly become a key technological tool for determining the significance of citizens as economic subjects in South Asia. We are concerned with elucidating how individuals consent or are coerced into participating in biometric programs (Gramsci 1971).

\section{Biometrics}

Social science research on biometrics identifies several critical concerns about the promise and implementation of these biotechnologies. The commercial-security discourse surrounding biometric technologies emphasize the impartiality offered with this technology in order to free individual identity from human prejudices. However, Magnet (2011) argues that racial stereotypes are often built into the design and functionality of biometric technologies. Biometric passport control systems have been critiqued for perpetuating "systematic asymmetric categorizations" (Hakli, 2007: 140). Kruger et al. (2008) view these categorizations as a form of violence that reduces the complexities of the body to databases as techniques of biopower. When these technologies operate as virtual bordering processes, they reinforce sovereign territorial power through securitization (Muller, 2011).

Amoore $(2009,2013)$ focuses on the operationalization of biometrics. She examines the ways in which bodies are sorted at the border and how these categorizations become a source of prediction and risk prevention. Risk-dominated security regimes integrate biotechnologies as methods of identity surveillance and spatial strategies for isolating unwanted or foreign "others" (Martin, 2010, 2012). Mobility and migration are additional areas where biometric technologies have been examined by geographers, such as the tracking of temporary migratory laborers in Canada, as part of a global program that promotes interstate management of temporary, 
short-term laborers (Pero and Smith, 2014). The introduction of geo-location biometrics such as geographic positioning systems (GPS) includes "geo-tagging" to track individuals in an effort to prevent violence or fraud, and improve the accuracy of information (Al-Assam et al., 2013). Correspondingly, biometric use offers a binary framework, which allows or denies access based on the sociopolitical data associated with one's biometric map (Nayar, 2012, Lyon, 2007, 2009).

The demands of the market and the desire of states to manage and maintain the secure and legal flow of migratory labor illustrate one of the many intersections between the state as an arbiter of security and the market's interest in managing risk and the flow of goods, people and services across geographic space. The extensive uses of sorting technologies reveal unequal spatial ordering and structures associated with neoliberal economic and service regimes (Bialasiewicz et al., 2007, Graham, 2005). Contemporary neoliberal economic logics place market rationalities at the center of spatial production and have reorganized national security geographies (Cowen, 2010). Biometric technologies exemplify these new forms of state security and market-based logics for managing risk and ensuring security. Therefore, it is important to increase our understanding of biometric uses within economic development and security practices.

\section{Biometric Usage in South Asia}

These recent developments in South Asia must be situated in the longer history of population registration, economic development and nation building (Szreter, 2007). Ajana (2013) provides genealogy of biometrics and theorizes the biopolitical implications of these technologies. Palm prints and fingerprints, along with general rationalized systems of names and identities, were part of colonial and imperial projects (McCoy 2009, Sarkar, 2014, Caplan \& Torpey, 2001). By the late 19th century, both colonial administrators and scientists with eugenic inclinations in Europe envisioned fingerprints and facial images as bodily markers of criminality and guides for heritable racial characteristics (Maguire, 2009). At the same time, passports were not only being invented to assign citizenship, but also to allow movement both within nations and between nations during an era of increased restrictive borders for labor mobility (Torpey, 2000). As these technologies of passports and fingerprints became normalized in the increasingly securitized spaces of border crossing and police stations, by the end of the 20th century biometrics had been integrated in to workings of welfare agencies in the U.S. as a way to verifying the "deserving poor" (Kruger et al., 2008). State identification operated as an ad hoc process required of individuals situated at the social, economic and political margins and optional for those more closely aligned with the "ideal" citizen subject. The unevenness of identification was previously a component of geopolitical relations but increasingly has become part of intra-national migration, intra-state security and for citizens to access state services. Biometrics has been unevenly deployed based on disparate purposes and logics of state governance and capital flows. The spatial and situational details of these differences provide an important lens for examining the divergent linkages between citizen-subjects and the state under the rubric of security and economic development. Examining existing biometric usage in different geopolitically and economically linked countries (India, Nepal and Afghanistan) provides a starting point for pushing geographic inquiry into biometric usage further.

India's trajectory as a regional leader in South Asia parallels the country's investment in biometrics. India's implementation of biometric data collection through the Aadhaar/Unique Identification Program (Aadhaar/UIDAI) indicates a new economic development trend in South Asia. This program provides an important entry point for examining the growing role of biometrics in both government and economic development programs throughout the region. For Nandan Nilekani, former chairman of Aadhaar, this project marks a departure from previous state interventions toward alleviating poverty: "If 30 years back, we talked about roti, 
kapda, aur makaan (food, clothing and shelter) and in the last 10 years we have talked about bijli, sadak, paani, which is infrastructure (power, roads and water), then in the next 10 years, it is going to be about bank accounts, mobile numbers and Aadhaar"(cited in Roy, 2014: 140). Aadhaar provides a nationalized example of India's growing technological leadership. Biometrics in South Asia illustrates the burgeoning linkages between technological prowess, securing economic development and national identity.

India's Aadhaar/UIDAI is expected to assist with many aspects of state security and to prevent fraud and identity inaccuracies within India's existing government bureaucracy. As Rao and Greenleaf (2013) show this program is not singular, but multiple. The Aadhaar/UIDAI program is expected to help with public distribution systems by routing out duplicate or fake beneficiaries because the provisions will be directly linked to individual biometrics (Saxena, 2012). It is also expected to increase efficiency across different departments and sectors of governance, efficient and easy methods for updating information, and "foolproof" identification (Patnaik and Gupta, 2010). However, there are human and technological errors associated with the use of these technologies (Rao, 2013, Patnaik and Gupta, 2010). The Aadhaar/UIDAI program may guarantee identity, but it does not obtain the capacity to guarantee rights, entitlements or benefits (Ramanathan, 2010).

The Aadhaar/UIDAI program offers an individualized system of existing state welfare and development programs. For example, Aadhaar/UIDAI seeks to individualize state verification of citizens in an attempt to individualize the connection between the state and citizens rather than between the state and communities (Nayar, 2012). Linking biometric data to cash distributions through banking and other community-based mechanisms for accessing state-welfare funds is another expected use of this technology (Chaudhuri and Somanathan, 2011). In the event of natural disaster or accidents, the Aadhaar/UIDAI program is identified as a method for effectively and quickly identifying victims and survivors (Rao, 2011). For example, in Nepal, biometric data have been used as a key technology for post-earthquake search and recovery efforts. Additionally, biometrics has been folded into other technological uses in India toward an e-government ideal.

In India, e-government has become a term to identify the increasing role (and promise) of technology as an agent of governance. There are four categories of e-government applications: (1) Government-to-Citizen, (2) Government-to-Business, (3) Government-to-Government and (4) Government-to-Employee (Gudavalli M et al., 2014). While Ursula Rao (2013) has examined data management and the workings of the Indian government, more research is needed to elucidate how e-governance is translated to citizens, businesses and other governments through both the state and non-governmental organizations.

The U.S. military fostered the implementation and collection of biometric data in Afghanistan as part of the U.S.-led military occupation of the country. The U.S. Department of Defense's (DOD) estimates $\$ 3.5$ billion will be spent on this biometric program by 2015 . Removing anonymity and categorically identifying people from amid complex social and family-based networks remain the primary interest for the DOD's collection and management of biometric data on civilian populations (Buhrow, 2010). The DOD has helped Afghanistan to establish, the Afghan Automated Biometrics Identification System (AABIS), which is in the process of collection data at a national scale (Mansfield-Devine, 2012). In order to receive a new or renew an old passport or identity card in Afghanistan, citizens must comply with various biometric screenings. Additionally, former Taliban or other insurgent groups interested in joining the "peace process" must agree to biometric identity scans (ISAF 2012).

Biometrics arrived in Nepal as part of shifting development paradigms that favored neoliberal economics and market driven capitalism. In line with neoliberal economic interventions, development programs are now targeting individuals, especially poor women, landless communities 
and peasants, as a priority for development and a source of economic growth. Biometric data collection is considered an important technology for identifying individuals, and NGOs and banks have become the primary biometric data collection centers (NRB, 2011).

Nepal's relationship with these new technologies operates on similar economic development logics, while citizen/subjects reliance on the services occurs through NGOs as seen with the post-earthquake recovery efforts. Examining the spatial and place-based divergences associated with the promise, use and implementation of these technologies deepens our understanding of the interrelationships between the economic and political interest in biometrics and the social implications of its incorporation into daily life. As argued by Mordini and Rebera (2012), identification technologies should be mutual, dialogical and involve reciprocal recognition. The sharing of biometrics with allies has become integrated into various state discourses, while the mechanisms for this sharing remain unclear. As these examples show, biometrics has come to represent a method for identification and tracking individuals toward state and economic development security.

\section{Geopolitics, Biopolitics and Biometrics}

Inclusion through biometrics in South Asia has become both a governmental and nongovernmental project that allows us to rethink concepts such as biopolitics, governmentality and neoliberal subjectivities. Since biometrics is fundamentally about translating populations into data, it is essential to understand the ways in which these data are defined, stored and shared. Development and poverty alleviation in South Asia are being reconfigured through these new technologies. Economist Paul Collier (2007) introduced the category of the "bottom billion" to describe a global population stuck in poverty. While previous regimes of development have taken global poverty alleviation as part of state building, the predominant methods now seek direct intervention by non-state actors. Ananya Roy (2012) has explored how this intervention is constructed as a financial opportunity, what some have labeled "bottom billion capitalism" or the "fortune at the bottom of the pyramid" (Prahalad, 2005).

By researching how varied populations that make up the "bottom billion" in India, Nepal and Afghanistan opens new avenues of how individuals and communities become captured through biometrics. Research on Global South biometrics provides an opportunity to extend and reconfigure the theories of biopolitics and governmentality (Foucault, 2003b, Foucault, 2003a, Foucault, 2007, Rose, 2001, Elden, 2007b, Stoler, 2006) by showing the specific geographic contours of how "new" state and economic regimes are being constructed through the use of biometrics (also see Ajana 2013). While Foucault has been used to look at state identification and institutional control (Legg, 2005, Philo, 2005, Hannah, 2000), we argue for more research on biometrics that examines the linkages, fractures and fissures between individual bodies, economic structures and state governance. We seek to address biometric technologies as they intersect with geopolitical and geo-economic security, which suggests a new iteration of Foucault's theories of biopolitics. For Foucault, "discipline is isolating, working on measures of segmentation, while security seeks to incorporate, and distribute more widely" (Elden, 2007a, Elden, 2007b). Technologically supported security includes evaluations of risk and probability based on algorithms with economic cost calculations (Amoore, 2013). Security is exercised over a population and operates in different places in a variety of ways. Threats are not to be eliminated, but rather probable situations are to be predicted. For Foucault, security opens up a future that is not quite controllable or measurable based upon what might happen, as a "series of events." Importance and recourses are allocated to the uncertain. Biometric technologies promise a technological fix for uncertainty as a method to visualize, identify and quantify risk. 
Biometrics in South Asia is a very specific apparatus of Foucauldian security that differs depending on geographic sites and institutional arrangements. We suggest that this particular iteration of biopolitical technologies in South Asia illustrate the multiplicity of governmentality (Chakrabarty, 2000, Hart 2004). For example, Aadhaar translates as "foundation" or "support". As Nilekani notes, "The name Aadhaar communicates the fundamental role of the number issued by the UIDAI, the number as a universal identity infrastructure, a foundation over which public and private agencies can build services and applications that benefit residents across India" (Planning-Commision-Government-of-India, 2012). This "foundation/support" through biometric technology opens up many possibilities and uncertain events to be predicted, from the starting of small business, to the migration of laborers, or identification of insurgents.

Both combatants in Afghanistan and debt defaulters in Nepal are not to be eliminated but included into this apparatus of security. Biometrics inclusion does not necessarily control the unknown but rather opens up new possibilities for discipline within particular geopolitical arrangements in South Asia. This emerging articulation of economy-discipline-governance diverges from some of the existing literature that incorporates Foucauldian theories with the study of development (Hart, 2004). We argue that it is necessary to explore these transformations, at the scale of the "rule of experts" (Mitchell, 2002) by examining the developers of this technology in tandem with officials implementing and collection data, and its interface with citizen/subjects as data.

This model of biometric development is predicated on "being seen." Accordingly, parallels exist between biometrics and the practices outlined by Scott's (1998) "Seeing like a State" in his historical examination of "legibility" and "simplification" which state officials sought to rationalize and standardize. The relationship between state and civil society through bureaucracy is not necessarily new but rather being reconfigured through the use of technology. Biometrics - touted as an efficiency and anti-corruption innovation - is also a new form of bureaucracy that comes with both pre-existing and new complications (Arendt, 1970, Weber, 2002). Whether biometrics will exacerbate or cut through the tensions and paperwork of bureaucracy in South Asia (Gupta, 2012) remains to be seen. Thus, critical geopolitical research is necessary to question if rendering visible marginalized populations or individuals identified as security "risks" provides a mechanism for incorporation or further marginalization through new (and fully accepted) technologies of discipline and control.

This bureaucratic inclusion through biometrics is predicated on an array of private investments and technical infrastructures. This combination of bodies, technology and investment is best theorized through what has been called the bio-economy or biocapital (Rajan, 2006, Cooper, 2008, Waldby and Mitchell, 2006, Rajan, 2012). While this literature looks at the relationship between geopolitics and economics in the realm of pharmaceuticals and genetics, we suggest there are multiple mobilizations of the bio-economy in relation to biometric knowledge, technological expansion and the systems of exchange and command through biodata. Nayar (2012) has begun to explore these in relation to biometrics in India by interrogating such themes as rematerialized bodies, epidermalization and somatically legible subjects.

Birch and Tyfield (2012) critique this literature for neither being specific in terms of economic exchanges nor in determining value within the bio-economy. Therefore, attention must be paid to the labor of those enrolled, those who enroll and the workers who code and manage the technology: all along the bio-commodity chain and the algorithms that interpret said data.

One of the emerging linkages between venture capitalist and the state is the investment in and use of biometric technologies toward biomedical interventions and fostering livelihoods for the poor. However, this is a very particular version of global health, related to humanitarian ventures, NGOs and venture capitalists (McGoey, 2014). The existing global health literature in geography (Brown et al., 2012, Craddock, 2007, Sparke, 2009, Sparke, 2014, Ingram, 2005) 
does not examine the emerging use of technologies such as biometrics as part of healthdevelopment paradigms in the global south. The relationships between multinational development organizations and health have produced new forms of biological citizenship (Nguyen, 2010, Petryna, 2007, Petryna, 2013). These emerging state-citizen relations through biometrics require being visible to both the state and international agencies as a precursor to health treatment. As bio-medicalization has come to dominate the realm of healthcare provisioning that reconfigures the unevenness of these geographies. Biomedicine and technoscience merge and reconfigure health as a moral obligation, a commodity and a mark of status and self-worth (Clarke, 2010). Biometrics is merely the latest iteration of how health has become infused with start-up business culture as bio-capital (Rajan, 2006, Dumit, 2012). Health products and services have become a growth sector that increasingly relies on speculation of investments and the promotion of national tech sectors or technological transfers through geopolitical relations.

The entrepreneurial turn in biometric technology and healthcare applications can be seen as a part of a general shift as "bottom billion capitalism seeks to convert the extreme poor into entrepreneurial subjects" (Roy, 2012). This emerging form of neoliberal subjectivity enabled through biometrics in South Asia is a particular reworking of economic theories of human capital by economists such as Gary Becker. As Mirowski (2013: 96) helps to contextualize the rise of the entrepreneurial self and the moral economy, he states "Foucault was the first to insist that Becker's 'human capital' was a first move in the neoliberal disintegration of the self." This takes on a very specific valence in South Asia, as can be seen in Nilekani's popular book Imagining India (2009). Nilekani returns to past fears of urban overpopulation by reframing India's population as potential human capital and a solution for global competitiveness (Zachariah, 2011). This population is envisioned as the source for unleashing South Asia as a global powerhouse through a geographically specific articulation of discipline, governance and the economy arising from Foucault's genealogy.

\section{Conclusion}

The promise of inclusion brought forth by biometric technologies contributes to the ongoing discussions in geography on how surplus population; race, waste and neoliberalism (Gidwani and Reddy, 2011, Katz, 2011, McIntyre, 2011, Yates, 2011) have become determined over time and seen as a source of future value. We are interested in "the how" of this inclusion and the translation of human capital from waste to value. The technological promise of incorporating the "bottom-billion" into nations through development programs has identified visualization of identity as necessary for securing this transfer. In this review, we have shown the intersections between state-based regulatory actions such as biometrics as a method for legitimizing the rule of the state along with the "free" and secure flow of capital investment, production and consumption.

By tracing out and theorizing the different forms of biometrics in India, Afghanistan and Nepal, we acknowledge that there are three core processes. The first process of biometrics is universalizing an attempt to document and render visible the state's citizenry. The second process seeks to isolate threats, an attempt to target and contain risky individuals as a violence prevention strategy. The third process is to assist those in need, an attempt to both support economically disadvantaged and catch others looking to cheat assistance systems. While place matters in the articulation of these processes among and within different countries, biometrics is being articulated as a universalizing method of security toward economic development. We argue that although biometrics is swiftly becoming a method of state and international security - in many respects it remains a manipulative tool. By seeing biometrics as a tool and looking at its usage in multiple sites - a place and situational expression of this technology emerges. In 
a commercial sense, the multiple usages and manipulation of biometric technologies provide various and ever increasing opportunities. For a state, biometrics on the one hand fits neatly within already existing structures of biopolitics, while on the other hand it can be a malleable tool of governance. E-governance incorporates citizen/subjects while it can also use "definitive technological proof' to detain, detach and disregard individuals or groups defined by the state as a security or economic risk. Thus, while biometrics is touted as a cure or fix for the ills of bureaucracy and human failures, it is similar to other tools of governance that can be wielded to meet the state's rather than the citizens' agendas and needs. It is imperative to study the implementation, uses and daily practices associated with biometric technology in order to elucidate the material practices that are often rendered invisible through the discursive framings of techo-security's visibilities.

The promise of biometrics in South Asia does not address the spatial, situational and everyday uses of these technologies. Thus, we call for an evaluation of biometrics through qualitative methodologies in order to examine the everyday-ness of these technologies and their various fragmentations. As geographers, our examination of biometrics seeks to explicate the ways in which these technologies offer market-driven technological solutions to bureaucratic redundancy and improved state and economic security. Since biometrics translates people into data for the purposes of state, security and economic legibility how does the everyday use of these technologies operate ontologically, discursively and epistemologically to ensure citizen security and improve livelihoods? What is the role of place, scale and context in the development, implementation and usage of biometric technologies? We poise these questions in an effort to begin a larger conversation about the geographies of "universalizing" security technologies, by examining place-based implementation of biometric technologies and how these technologies mitigate citizen/subjects interactions with state and non-state actors within an economic development and security framework.

\section{Notes}

* Correspondence address: Jennifer L. Fluri, University of Colorado-Boulder, Geography Department. E-mail: Jennifer. Fluri@Colorado.EDU

1 http://www.bbc.com/news/world-asia-india-29175870

\section{References}

Ajana, B. (2013). Governing through biometrics: the biopolitics of identity. Macmillan: Palgrave.

Al-Assam, H., Lami, I. A. and Kuseler, T. (2013). Integrating cancellable biometrics with geographical location for effective unattended authentication of users of mobile devices. Journal of Communications 8.

Amoore, L. (2009). Algorithmic war: everyday geographies of the war on terror. Antipode 41, pp. 49-69.

Amoore, L. (2013) The politics of possibility: risk and security beyond probability.

Arendt, H. (1970). On violence. New York: Harcourt, Inc.

Bialasiewicz, L., Campbell, D., Elden, S., et al. (2007). Performing security: the imaginative geographies of current US strategy. Political Geography 26, pp. 405-422.

Birch, K. and Tyfield, D. (2012). Theorizing the bioeconomy: biovalue, biocapital, bioeconomics or ... What? Science, Technology \& Human Values 38, pp. 299-327.

Brown, T., Craddock, S. and Ingram, A. (2012). Critical interventions in global health: governmentality, risk, and assemblage. Annals of the Association of American Geographers 102, pp. 1182-1189.

Buhrow, W.C. (2010). Using biometrics in Afghanistan. ARMY February.

Caplan, J. and Torpey, J. (Eds) (2001). Documenting individual identity: the development of state practices in the modern world. Princeton, NJ: Princeton University Press. 
Chakrabarty, D. (2000). Provincializing Europe: postcolonial thought and historical difference. Princeton, NJ: Princeton University Press.

Chaudhuri, A. R. and Somanathan, E. (2011). Cash transfers to individuals based on biometric identification are feasible and will bring large gains to the economically insecure (No. 11-04). New Delhi, India: Indian Statistical Institute.

Clarke, A. (2010). Biomedicalization: technoscience, health, and illness in the U.S. Durham, NC: Duke University Press.

Collier, P. (2007). The bottom billion: why the poorest countries are failing and what can be done about it. Oxford; New York: Oxford University Press.

Cooper, M. (2008). Life as surplus: biotechnology and capitalism in the neoliberal era. Seattle: University of Washington Press.

Cowen, D. (2010). A geography of logistics: market authority and the security of supply chains. Annals of the Association of American Geographers 100, pp. 600-620.

Craddock, S. (2007). Market incentives, human lives, and AIDS vaccines. Social Science \& Medicine 64, pp. 1042.

Duffield, M. R. (2007). Development, security and unending war: governing the world of peoples. Cambridge: Polity.

Dumit, J. (2012). Drugs for life: how pharmaceutical companies define our health. Durham, NC: Duke University Press.

Elden, S. (2007a). Governmentality, calculation, territory. Environment and Planning D: Society and Space 25, pp. 562-580.

Elden, S. (2007b). Rethinking governmentality. Political Geography 26, pp. 29-33.

Foucault, M. (2003a). Abnormal: lectures at the College de France, 1974-1975. New York: Picador.

Foucault, M. (2003b). Society must be defended: lectures at the College de France, 1975-76. New York: Picador.

Foucault, M. (2007). Security, territory, population: lectures at the College de France, 1977-78. New York: Palgrave Macmillan.

Gidwani, V. and Reddy, R. N. (2011). The afterlives of "waste": notes from India for a minor history of capitalist surplus. Antipode 43, pp. 1625-1658.

Graham, S. D. (2005). Software-sorted geographies. Progress in Human Geography 29, pp. 562-580.

Gramsci, A. (1971). Selections from the prison notebooks of Antonio Gramsci. New York: Lawrence and Wishart.

Gudavalli, M., Srinivasa, K. D. and Viswanadha, R. S. (2014). Securing e-governance services through biometrics. Applied International Journal of Security and its Applications 8, pp. 103-112.

Gupta, A. (2012). Red tape: bureaucracy, structural violence, and poverty in India. Durham: Duke University Press.

Hakli, J. (2007). Biometric identities. Progress in Human Geography 31, pp. 139-141.

Hannah, M. G. (2000). Governmentality and the mastery of territory in nineteenth-century America. New York: Cambridge University Press.

Hart, G. (2004). Geography and development: critical ethnographies. Progress in Human Geography 28, pp. 91-100.

Ingram, A. (2005). The new geopolitics of disease: between global health and global security. Geopolitics 10, pp. 522-545.

Katz, C. (2011). Accumulation, excess, childhood: toward a countertopography of risk and waste. Documents d'Anàlisi Geogràfica 57, pp. 47-60.

Kruger, E., Magnet, S. and Van Loon, J. (2008). Biometric revisions of the "body" in airports and US welfare reform. Body E Society 14, pp. 99-121.

Le Billon, P. (2008). Diamond wars? Conflict diamonds and geographies of resource wars. Annals of the Association of American Geographers 98(2), pp. 345-372.

Legg, S. (2005). Foucault's population geographies: classifications, biopolitics and governmental spaces. Population, Space and Place 11, pp. 137-156.

Lyon, D. (2007). Surveillance studies: An overview. Polity.

Lyon, D. (2009). Identifying citizens: ID cards as surveillance. Polity.

Magnet, S. (2011). When biometrics fail: gender, race, and the technology of identity. Durham, NC: Duke University Press.

Maguire, M. (2009). The birth of biometric security. Anthropology Today 25(2), pp. 9-14.

Mansfield-Devine, S. (2012). Biometrics at war: the US military's need for identification and authentication. Biometric Technology Today 2012, pp. 5-8.

Martin, L. L. (2010). Bombs, bodies, and biopolitics: securitizing the subject at the airport security checkpoint. Social \& Cultural Geography 11, pp. 17-34.

Martin, L. L. (2012). "Catch and remove": detention, deterrence, and discipline in US noncitizen family detention practice. Geopolitics 17, pp. 312-334.

McCoy, A. W. (2009). Policing America's empire: the United States, the Philippines, and the rise of the surveillance state. Madison, WI: University of Wisconsin Press.

McGoey, L. (2014). The philanthropic state: market-state hybrids in the philanthrocapitalist turn. Third World Quarterly 35(1), pp. 109-125.

McIntyre, M. (2011). Race, surplus population and the Marxist theory of imperialism. Antipode 43, pp. 1489-1515.

Mitchell, T. (2002). Rule of experts: Egypt, techno-politics, modernity. Berkeley: University of California Press.

Mirowski, P. (2013) Never let a serious crisis go to waste: how neoliberalism survived the financial meltdown.

Mordini, E. and Rebera, A. P. (2012). No identification without representation: constraints on the use of biometric identification systems. Review of Policy Research 29, pp. 5-20. 
Muller, B. J. (2011). Risking it all at the biometric border: mobility, limits, and the persistence of securitisation 1. Geopolitics 16, pp. 91-106.

Nayar, P. K. (2012). "I sing the body biometric": surveillance and biological citizenship. Economic E Political Weekly, pp. 17-22.

Nepal Rastra Bank (NRB). (2011) Enhancing Access to Financial Services (EAFS) Project, Project Overview Report 2010 and 2011. Microfinance Promotion and Supervision Department, Central Bank of Nepal, Kathmandu, Nepal.

Nguyen, V.-K. (2010). The Republic of Therapy: Triage and Sovereignty in West Africa's Time of AIDS. Durham, N.C.: Duke University Press.

Nilekani, N. (2009). Imagining India: the idea of a renewed nation. New York: Penguin Press.

Patnaik, A. and Gupta, D. (2010). Unique identification system. International Journal of Computer Applications 7 , pp. 46-51.

Pero, R. and Smith, H. (2014). In the "service" of migrants: the temporary resident biometrics project and the economization of migrant labor in Canada. Annals of the Association of American Geographers 104, pp. 401-411.

Petryna, A. (2007). Clinical trials offshored: on private sector science and public health. BioSocieties 2, pp. 21-40.

Petryna, A. (2013). Life exposed biological citizens after Chernobyl. Princeton, N.J.; Woodstock: Princeton University Press.

Philo, C. (2005). Sex, life, death, geography: fragmentary remarks inspired by "Foucault's population geographies. Population, Space and Place 11, pp. 325-333.

Planning-Commision-Government-of-India. (2012) UIDAI-Concept. Available at: http://uidai.gov.in/uid-brand/concept.html.

Prahalad, C. K. (2005). The fortune at the bottom of the pyramid. Upper Saddle River, NJ: Wharton School Pub.

Rajan, K. S. (2006). Biocapital: the constitution of postgenomic life. Durham: Duke University Press.

Rajan, K. S. (2012). Lively capital: biotechnologies, ethics, and governance in global markets. Durham: Duke University Press.

Ramanathan, U. (2010). A unique identity bill. Economic \& Political Weekly, pp. 3-9.

Rao, A. S. R. S. (2011). Biometric cards for the Indian population. Asian Population Studies 7, pp. $295-300$.

Rao, U. (2013). Biometric marginality: UID and the shaping of homeless identities in the city Ursula. Economic E Political Weekly xlviII(13), pp. 71-77.

Rao, U. and Greenleaf, G. (2013). Subverting ID from above and below: the uncertain shaping of India's new instrument of e-governance. Surveillance \& Society 11(3), pp. 287-300.

Rose, N. (2001). The politics of life itself. Theory, Culture and Society 18, pp. 1-30.

Roy, A. (2010). Poverty capital: microfinance and the making of development. New York: Routledge.

Roy, A. (2012). Subjects of risk: technologies of gender in the making of millennial modernity. Public Culture 24, pp. 131-155.

Roy, A. (2014). Slum-free cities of the Asian century: postcolonial government and the project of inclusive growth. Singapore Journal of Tropical Geography 35, pp. 136-150.

Sarkar, S (2014) The Unique Identity (UID) Project, Biometrics and Re-Imagining Governance in India. Oxford Development Studies, (June), 37-41.

Saxena, NC. (2012) Hunger and malnutrition in India. IDS Bulletin Volume 43.

Scott, J. C. (1998). Seeing like a state: how certain schemes to improve the human condition have failed. New Haven: Yale University Press.

Silvey, R. (2010). Development geography: Politics and "the state" under crisis. Progress in Human Geography 34(6), pp. $828-834$.

Silvey, R. and Rankin, K. (2011). Development geography critical development studies and political geographic imaginaries. Progress in Human Geography 35(5), pp. 696-704.

Sparke, M. (2009). Unpacking economism and remapping the terrain of global health. In: Kay, A. and Williams, O. (eds) Global health governance: transformations, challenges and opportunities amidst globalization. New York: Palgrave Macmillan, pp.131-159.

Sparke, M. (2014). Health. In: Lee, R., Castree, N., Rob, K., Lawson, V., Paasi, A., Radcliffe, S. and Withers, C. (eds) The SAGE handbook of progress in human geography. London: SAGE Publications Ltd.

Stoler, A. L. (2006). Haunted by empire: geographies of intimacy in North American history. Durham: Duke University Press.

Szreter, S. (2007). The right of registration: development, identity registration, and social security-a historical perspective. World Development 35(1), pp. 67-86.

Torpey, J. (2000). The invention of the passport: surveillance, citizenship and the state. Cambridge, UK: Cambridge University Press.

Waldby, C. and Mitchell, R. (2006). Tissue economies: blood, organs, and cell lines in late capitalism. Durham, N.C.: Duke University Press.

Weber, M. R. G. (2002). Economy and society: an outline of interpretive sociology. Berkeley: University of California Press.

Yates, M. (2011). The human-as-waste, the labor theory of value and disposability in contemporary capitalism. Antipode 43, pp. 1679-1695.

Zachariah, B. (2011). Playing the Nation Game: The Ambiguities of Nationalism in India. Delhi: Yoda Press. 


\section{Further Reading}

Comaroff, J. (2007). Beyond bare life: AIDS, (bio)politics, and the neoliberal order. Public Culture 19, pp. 197-219.

Edwards, S.C., and Adams, E.R. (2012) Biometrics use in the Department of Defense.

Farmer, P. (2005). Pathologies of power: health, human rights, and the new war on the poor. Berkeley: University of California Press.

Fluri, J. (2009). "Foreign passports only": geographies of (post) conflict work in Kabul, Afghanistan. Annals of the Association of American Geographers 99, pp. 986-994.

Franklin, S. and Lock, M. M. (2003). Remaking life E death: toward an anthropology of the biosciences. Santa Fe; Oxford: School of American Research Press; James Currey.

Gold, S. (2010). Military biometrics on the frontline. Biometric Technology Today 2010, pp. 7-9.

Gold, S. (2012). Preventing electoral fraud using biometrics. Biometric Technology Today 2012, pp. 5-6.

Goodhand, J. (2006). Aiding peace?: the role of NGOs in armed conflict. Boulder, Colo.: Lynne Rienner Publishers.

Green, M. (2012). Zeroing biometrics: collecting biometrics before the shooting starts.

Helmreich, S. (2008). Species of biocapital. Science as Culture 17, pp. 463-478.

Kak, A. U. and Malik, S. (2010). Privacy and the National Identification Authority of India Bill: leaving much to the imagination. NUJS Law Review 485, pp. 485-510.

Kaldor, M. (2007). Human security: reflections on globalization and intervention. Cambridge, Malden: Polity. 